\title{
$70 \mathrm{MW}$ 級低速応型超電導発電機の電気特性
}

$\begin{array}{rcc}\text { 正員 前田 } & \text { 進 } & \text { (三菱電機) } \\ \text { 増永 } & \text { 顕 } & \text { (三菱電機) } \\ \text { 正員 鈴木 } & \text { 一市 } & \text { (三菱電機) } \\ \text { 正員 上田 } & \text { 明紀 } & \text { (三菱電機) } \\ \text { 正員 米谷 } & \text { 晴之 } & \text { (三菱電機) } \\ \text { 正員 下畑 } & \text { 賢司 } & \text { (三菱電機) } \\ \text { 正員 平尾 } & \text { 俊樹 } & \text { (Super-GM) }\end{array}$

Electrical Performance of Slow Response Excitation Type Superconducting Generator Susumu Maeda, Ken Masunaga, Kazuichi Suzuki, Akinori Ueda, Haruyuki Kometani, Kenji Shimohata (Mitsubishi Electric Corporation) Toshiki Hirao (Super-GM)

\begin{abstract}
Superconducting generators have many advantages such as increasing generation efficiency, improving power system stability and reducing size and weight in comparison with conventional generators. In Japan, 70MW class superconducting generators (model machine) are being developed. Manufacture of "70MW class slow response excitation type rotor" started in 1992 and factory tests were conducted in 1996. Succeeding to the factory tests, the rotor was combined to the stator with air gap windings in the verification test facility (in Osaka power station) and verification tests were conducted in 1998. Satisfactory results which represent the advantages and the reliability of superconducting generators were obtained.

In this paper, test results of electrical characteristics of 70MW model generator such as "electrical constants" and "No load open/short circuit characteristics" are discussed. Evaluation by 3D magnetic analysis are also described. The main results are summarized below.

- The synchronouce reactance $\left(X_{d}\right)$ was 0.42 p.u. which is $1 / 4 \sim 1 / 5$ of conventional generators. $X_{d}$ can be analyzed precisely by 3D magnetic field analysis which is now taken into account for the effect of the armature end windings on electrical characteristics.

- $X_{d}$ " which is originated in "double layer damper system" was separated clearly from 3-phase sudden short circuit test.

These reactances can be analyzed by quasi-3D analysis considering the boundary condition of rotor surface .

- By means of these magnetic analyses, fundamental design methods considering the end windings were established. These are applicable to the design of "200MW class pilot superconducting generator".
\end{abstract}

キーワード : 超電導発電機、ロータ、超電導導体、リアクタンス、三次元磁界解析)

(superconducting-generator、rotor, superconductor, reactance、 three dimensional field analysis)

\section{1、まえがき}

界磁巻線を超電導化した超電導発電機は、効率向上、 電力系統の安定性向上といった利点があり、研究開発 が行われている。現在日本では、通商産業省工業技術 院のニューサンシャイン計画「超電導電力応用技術開 発」の一閴として 1988 年度からの 12 年計画により、 $200 \mathrm{MW}$ 級パイロット機の設計・製作に必要な技術 開発を目的とした「7 $0 \mathrm{MW}$ 級モデル発電機」(以下、 $70 \mathrm{MW}$ 級機亡略記）の開発が進められている(1。

この計画において、筆者らは低速応型機の開発を担 当しており、要素技術開発 ${ }^{(2)}$ 及び $70 \mathrm{MW}$ 級機ロータ
の縮長型である「ロータ部分モデル」(3) の成果を反映 して70 MW級機ロータの設阡・製作を進め、1996 年度には工場での回転励磁試験を実施した ${ }^{(4)}$ 。

また、1998年3月から9月にかけてステータと組合 せた現地実証試験を超電導組合試験センター（関西電 力 (株) 大阪発電所内) で実施した。超電導発電機とし ての基本特性検証試験、世界最大の79.7 MWの発電 試験、世界最長の1500時間の連続運転試験、三相突 発短絡試験を実施する等、試験は成功裹に終了した ${ }^{(5) 。 ~}$ 本論文は、電気基本特性である「無負荷飽和／三相 
短絡特性」、「発電機定数」に関する $70 \mathrm{MW}$ 級機の実 測結果、解析による評価について報告するものである。 $70 \mathrm{MW}$ 級機は以下に示す構造上の特徵を有する。 (1)空心構造を適用（ロー夕軸材に非磁性材料を使用、

ステータには鉄心歯部のない空腙巻線を使用)。

(2)かご型常温ダンパと円筒型低温ダンパからなる2 重 ダンパ構成を適用。

(3) $70 \mathrm{MW}$ 級機は $200 \mathrm{MW}$ 級パイロット機の同径縮 長型として設計されているため、電機子巻線值線部 が短く、相対的に巻線端部長が長い。

(1)〜(3)の構造上の特徵に対応して、超電導発電機は 以下の特性を有しており、これらの把握と定量評価が 開発の主要課題の一つである。

(1) 同期リアクタンスが現用機の $1 / 4 \sim 1 / 5$ に減少

(構造上の特徴(1)に対応)

(2) リアクタンスに次次過渡成分 $\left(X_{d}, ", X_{a}, "\right)$ が存在 (2)に対灾)

(3) 電機子巻線端部が発電機特性、定数に与える影響 が大 (3に対応)

$70 \mathrm{MW}$ 級機では、無負荷飽和／三相短絡特性試験 の他、負荷遮断試験を含む 5 種類の定数計測試験を実 施している。筆者らは(1)〜 (3) の点に留意し、実測結 果に対する解析評価を行った。

無負荷飽和 /三相短絡特性、及びこれから求まる同 期リアクタンスに関しては、ロータの回転を考慮した 三次元線形非定常磁界解析 ${ }^{(6)}$ を実施して、磁界分布定 含む評価を行った。三次元解析を実施することで従来 の二次元解析では困難であった電機子巻線端部が電気 特性に与える影響を考虑できるようになった。

過渡りアクタンスに関しては、三相突発短絡試験で 短絡電流の次次過渡、次過渡、過渡成分を分離でき、 对応するリアクタンスを求めることが出来た。現状の 解析技術ではダンパの導電率を考虑して発電機全体を モデル化した三次元解析を実施するのは困難であるこ とから擬似三次元解析 (7)を適用し、ロー夕表面に境界 条件を設定することで渦電流の効果を考慮してリアク
タンスを解析した。

解析の結果、無負荷 /三相短絡特性、リアクタンス を正確に算出可能との結果が得られた。電機子巻線の 端部発電効果を考慮した超電導発電機の設計手法を確 立できたと考える。この手法は、次期開発目標である $200 \mathrm{MW}$ W゚イロット機の設計にも適用可能である。

\section{2. $70 \mathrm{MW}$ 級機の仕様と弨電尊ロー夕の構成}

(1) 発電機定格と主要材料

$70 \mathrm{MW}$ 級低速応型モデル機の主要仕様とロータの 使用材料を表 1 に示す。

表 $170 \mathrm{MW}$ 級機の主要仕様

Table 1. Specifications of 70MW class model generator

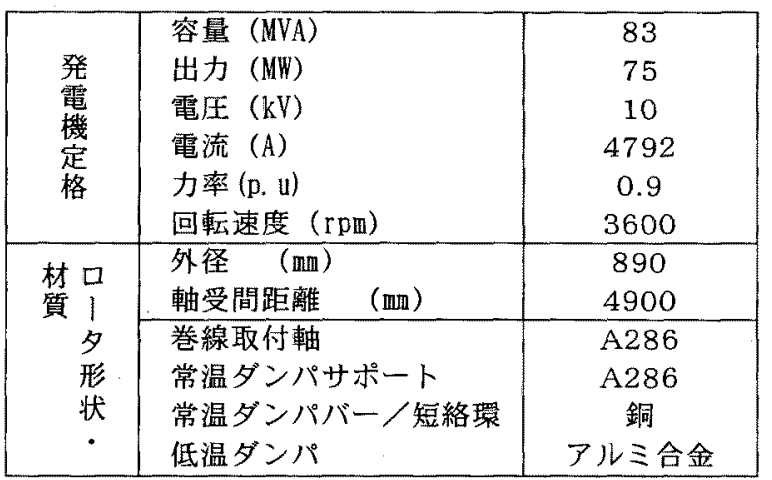

（2）低速応型 $70 \mathrm{MW}$ 級機口ー夕の特徵

$70 \mathrm{MW}$ 級機ロー夕の断面図を図 1 に示す。ロー夕 は超電導界磁巻線を液体へリウムで極低温に泠却する ため、真空断熱層を設けた多重円筒構造である。ロー タダンパは、室温のかご型常温ダンパと100K程度の 低温ダンバを設ける、いわゆる二重ダンパ構成として いる。常温ダンパは、支持円筒材外周のスロット内に 設置されたダンパ導体とロータ端部の短絡環とで、か ご型の完全全長ダンバを形成している。ダンパをロー タの表面に配置することで、冷却が良くなり、逆相耐 量の点で有利である。

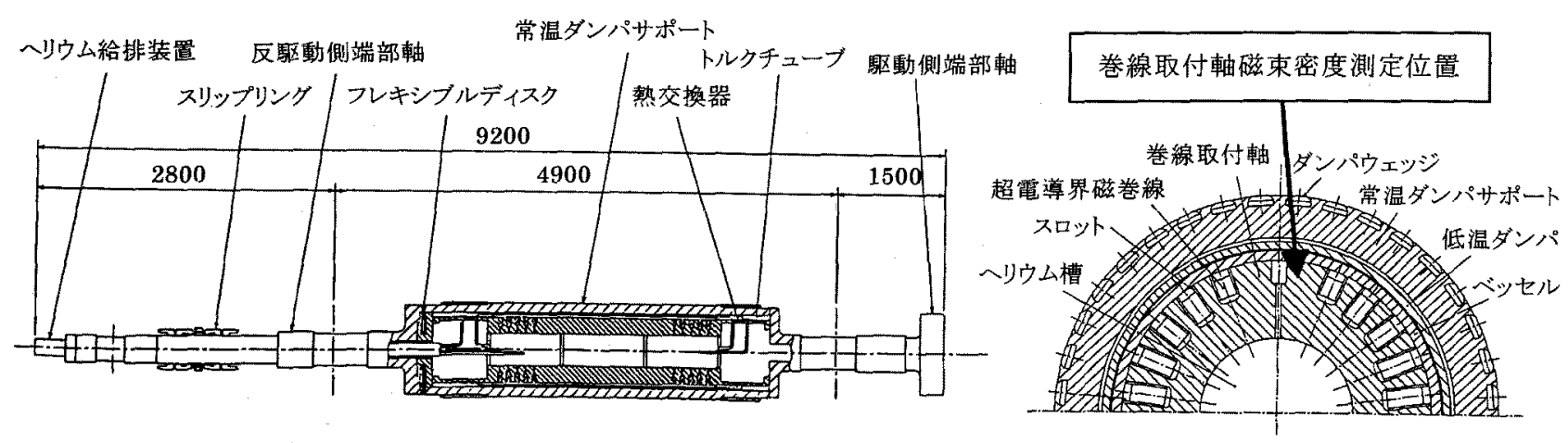

図 $170 \mathrm{MW}$ 級機口ー夕の断面図

Fig.1. Cross sectional views of $70 \mathrm{MW}$ class model rotor 


\section{3. 現地実証武験の結果}

電気特性の試験方法と得られた結果を表 2 に示す。

表 2 検証試験之評価項目

Table 2. Verification test items

\begin{tabular}{|c|c|}
\hline 試験項目 & 評価する電気特性 \\
\hline $\begin{array}{l}\text { (1)無負荷飽和 } \\
\text { 三相短絡特性試験 }\end{array}$ & $\begin{array}{l}\text { - 電気基本特性 } \\
\text { - 同期リアクタンス } \quad\left(X_{d}\right)\end{array}$ \\
\hline $\begin{array}{l}\text { (2)ダルトン・ } \\
\text { カメロン法 }\end{array}$ & 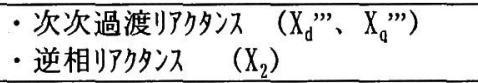 \\
\hline (3)ダンパ試験 & - 同期、逆相师多ンス $\quad\left(X_{d} 、 X_{2}\right)$ \\
\hline (4)単相短絡試験 & ・逆相师多ンス $\quad\left(X_{2}\right)$ \\
\hline $\begin{array}{l}\text { (5)三相突発短絡 } \\
\text { 試験 } \\
\end{array}$ & 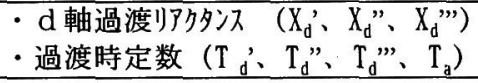 \\
\hline $\begin{array}{l}\text { (6)直軸 } \\
\text { 負荷遮断試験 }\end{array}$ & - $\mathrm{d}$ 軸师クンス、時定数 \\
\hline
\end{tabular}

\section{1 無負荷飽和特性、三相短絡特性武験}

\subsection{1 試験結果}

無負荷飽和特性試験では定格電圧 $10 \mathrm{kV}$ の $120 \%$ まで 励磁したが、磁気飽和は認められなかった (図 2)。定 格電圧時の界磁電流実測值 $\mathrm{I}_{\mathrm{f} 0}=2165 \mathrm{~A}$ に対し、三相短 絡特性試験での定格電流4792A時の界磁電流実測值は $\mathrm{I}_{\mathrm{f} 2}=919 \mathrm{~A}$ であった。両者から同期リアクタンス $\left(\mathrm{X}_{\mathrm{d}}\right)$ は、0.42p.u と求まる。現用機の $1 / 4 \sim 1 / 5$ の值が得ら れたことで、超電導発電機の特徽である空心構造のリ アクタンスに与える効果を確認した。

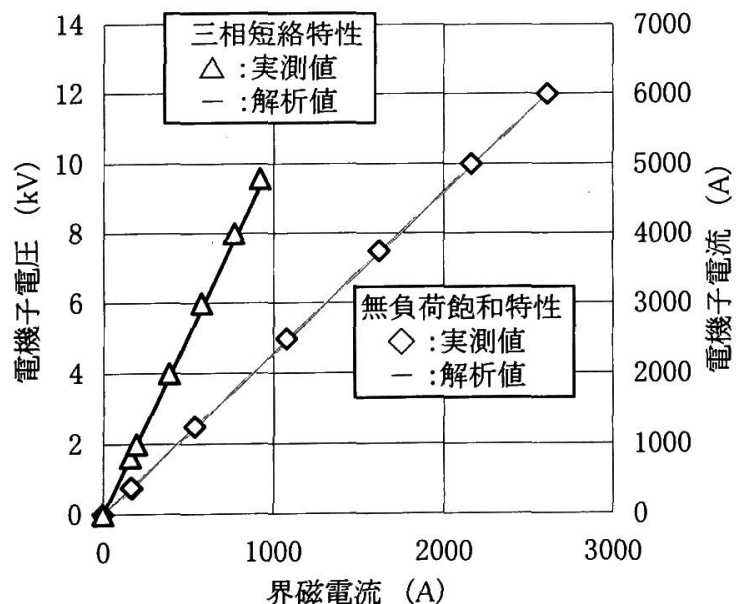

図 2 無負荷飽和 /三相短絡特性

Fig.2. No load open/short circuit characteristics

\section{1 .2 試験結果の解析との対比}

三次元磁界解析 ${ }^{(6)}$ を行い試験結果を評価した。解析 モデルの仕様を表 3 に、モデル（磁束密度分布解析結 果をあわせて表示) を図 3 に示す。解析では電機子巻
線端部及び㜞型の界磁巻線形状を正確にモデル化した。

表 3 解析モデルの仕様

Table 3. Specifications of 3-D field analysis

\begin{tabular}{|c|c|}
\hline $\begin{array}{c}\text { 節点数／ } \\
\text { 要素数 }\end{array}$ & $293,845 / 518,589$ \\
\hline 解析方法 & $\begin{array}{l}\text { - 線形（鉄心の透磁率一定）非定常解析 } \\
\text { ・ロータの回転を考慮 } \\
\text { ・ タイムステップ: } 20 \text { 分割／サイクル }\end{array}$ \\
\hline $\begin{array}{c}\text { 解析 } \\
\text { モデル }\end{array}$ & $\begin{array}{l}\text { • 電機子磁界と回転子は同期して回転す } \\
\text { るためダ 林、巻線取付軸はモデル化せず } \\
\text { •周期境界条件を用いて } 1 \text { 極分を解析 }\end{array}$ \\
\hline
\end{tabular}

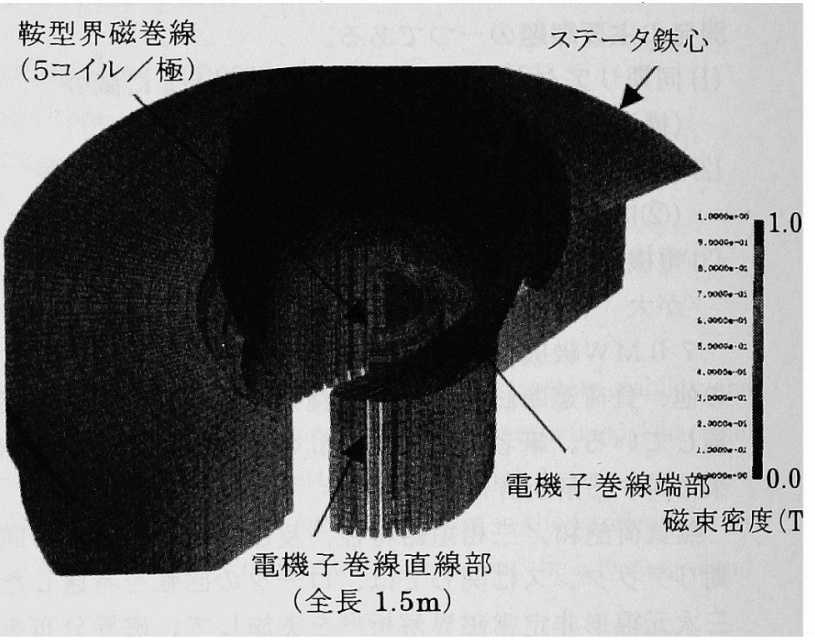

図 3 無負荷電圧発生時の発電機内磁界分布

Fig.3. Field distribution in 70MW model generator

\section{（1）ロー夕中央部の磁束密度}

巻線取付軸の軸方向中央の磁極部に設置したホール 素子（図 1 参照）により、無負荷電圧発生時、負荷運 転時に磁束密度計測を行った。無負荷電圧発生時の磁 束密度実測結果と解析結果を併せて図 4 に示す。

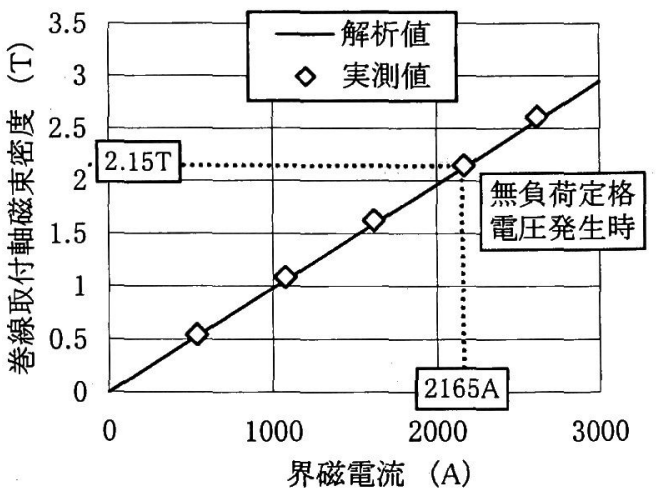

図 4 磁束密度計測結果（無負荷電圧発生時） Fig.4. Flux density at no load open circuit 
解析值と実測結果が良く一致していることから、界 磁巻線が発生する磁界に対して本モデルで精度良く解 析できることを確認した。次に界磁磁界と電機子磁界 の合成磁界で表される負荷時について磁束密度の実測 と解析を比較した(表 4)。計算した負荷条件は，定格 急荷点近搒（出力 83MVA, 0.96pf, 10kV, 4792A) であり、 合成条件を図 5 に示す。出力条件、内部相差角、力率 角には、何れも実測値を使用した。合成磁界について も本モデルで精度良く解析できることが確認できた。

表 4 負荷時の巻線取付軸磁束密度

Table 4. Flux density at load condition

\begin{tabular}{|c|c|c|}
\hline & 実測値 & 解析值 \\
\hline 磁束密度 & $2.44 \mathrm{~T}$ & $2.43 \mathrm{~T}$ \\
\hline
\end{tabular}

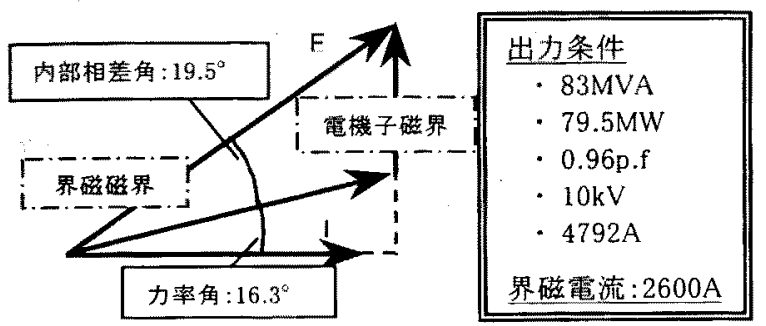

図 5 負荷の合成条件

Fig.5. Composition of rotor and stator flux

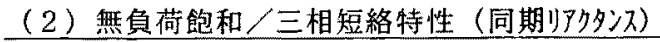

$70 \mathrm{MW}$ 級機は電機子鍈心長が約 $1.5 \mathrm{~m}$ と電機子巻 線端部長 (両側で約 $2 \mathrm{~m}$ ) より短く、電機子巻線端部 での発電効果の影警が大きい。二次元解析では、正確 な特性評価を行うのが困難であったが、三次元解析に より巻線端部形状を正確に考慮することで、無負荷飽 和、三相短絡特性とも実测值とほぼ一致する結果が得 られた（图 2 )。解析結果から求めた同期りアクタン スは0.43(p.u)とほぼ実䁚絓果と一致した（表 5)。

表 5 界磁電流及び同期りアクタンス Table.5. Measured results of synchronous reactance

\begin{tabular}{|c|c|c|c|}
\hline & $\begin{array}{c}\text { 無負荷飽和時 } \\
(\text { 定格 } 10 \mathrm{kV})\end{array}$ & $\begin{array}{c}\text { 三相短絡時 } \\
(\text { (定格 } 4792 \mathrm{~A})\end{array}$ & 同期将多入 \\
\hline 実測值 & $2165(\mathrm{~A})$ & $919(\mathrm{~A})$ & $0.42(\mathrm{p} . \mathrm{u})$ \\
\hline 解析值 & $2178(\mathrm{~A})$ & $939(\mathrm{~A})$ & $0.43(\mathrm{p} . \mathrm{u})$ \\
\hline
\end{tabular}

\section{2 過渡時のリアクタンス}

$70 \mathrm{MW}$ 機のリアクタンス、時定数を測定するため。 表6の(2) (6)の試験を実施した。表には試験法と試験 時の発電機内の磁界分布との関連を示す。

表 6 試験方法と磁界分布

Table 6. Measurements of reactances

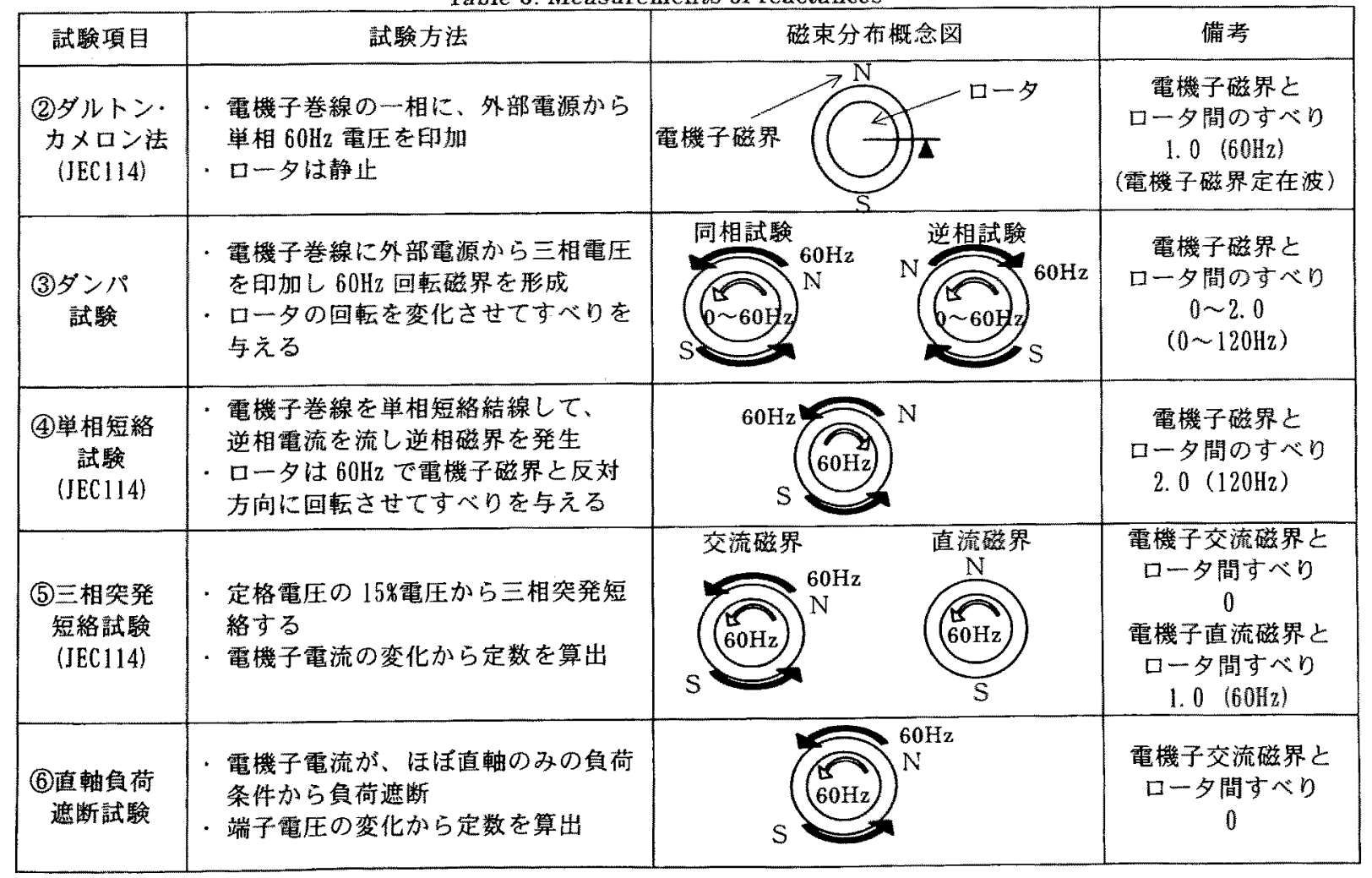

: 電機子から発生する磁界の回転方向を示す

く：ロータの回転方向を示す 


\section{2 .1 試験結果}

\section{(1) ダルトン・カメロン法}

定在波電機子磁界に対するリアクタンスを計测した（表 7 )。磁界変化が $60 \mathrm{~Hz}$ であり、電機子磁界はほぼ常温ダン パで遮蔽されるため、 $\mathrm{X}_{\mathrm{d}}{ }^{\prime \prime}, \mathrm{X}_{\mathrm{q}}{ }^{\prime \prime}, \mathrm{X}_{2}$ に対応する磁界分布之 同等である。 $X_{d}{ }^{\prime}=X_{a}$ ”之突極性のないことを確認した。

表 7 ダルトン・カメロン法の試験結果 Table 7. Measurement of $X_{d}^{\prime \prime} X " X^{\prime}$

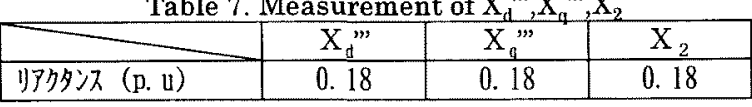

\section{(2) ダンバ試験}

界磁回路オープンの状態で、電機子磁界とロータ間にすべ り 0 ～2.0 (0〜 120Hz) を与えた条件でリアクタンスを計測 した。すべりとリアクタンスの関係を図6に示す。すべり 0 $(\mathrm{OHz})$ の場合は、電機子磁界はロー夕を貫通して流れ、磁 界分布はX $\mathrm{X}_{\mathrm{d}}$ に対応する分布と同等である。すべり 2.0

$(120 \mathrm{~Hz})$ の条件ではX,

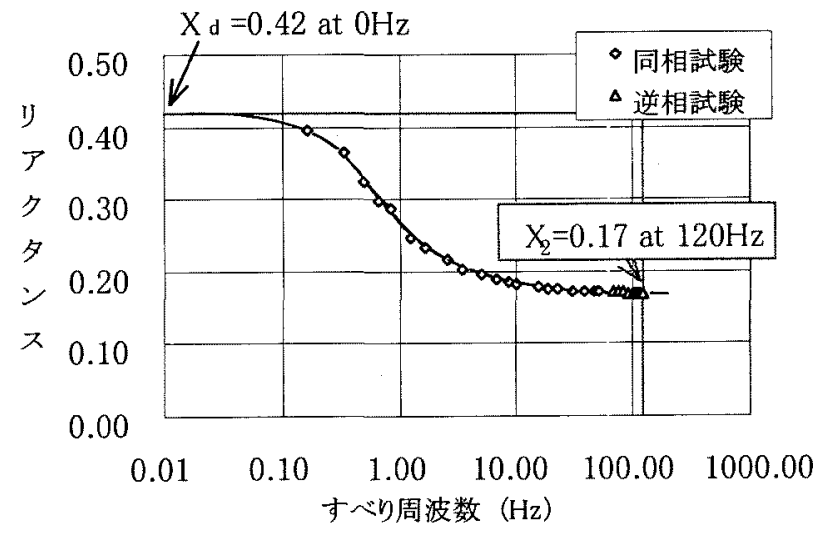

図6 ダンパ試験結果（リアクタンス）

Fig.6. relationship between slip and reactance

\section{(3) 単相短絡試験}

逆相磁界に対するX 2 を計測した（表 8)。 $\mathrm{X}_{2}=0.17 \mathrm{p} . \mathrm{u}$ と、 ダルトンカメロン法、ダンパ試験結果と同等の結果が得られた。

表 8 単相短絡試験の試験結果

Table.8. measurement of $\mathrm{X}$

\begin{tabular}{|c|c|c|c|}
\hline $\begin{array}{c}\text { 電機子短絡 } \\
\text { 電流 }(\mathrm{A})\end{array}$ & $\begin{array}{c}\text { 開放相電圧 } \\
(\mathrm{V})\end{array}$ & $\begin{array}{c}\text { 界磁電流 } \\
(\mathrm{A})\end{array}$ & $\begin{array}{c}\text { 逆相归誃次 } \\
\mathrm{X}_{2}(\mathrm{p} . \mathrm{u})\end{array}$ \\
\hline 700 & 253 & 110 & 0.17 \\
\hline
\end{tabular}

\section{(4) 三相突発短絡試験}

三相突発短絡試験時の端子電圧、短絡電流と界磁電流の 実測結果を図 7 に示す。短絡電流変化から過渡リアクタン ス $\left(\mathrm{X}_{\mathrm{d}}{ }^{\prime}, \mathrm{X}_{\mathrm{d}}{ }^{\prime}, \mathrm{X}_{\mathrm{d}}{ }^{\prime \prime}\right)$ 、過渡時定数 $\left(\mathrm{T}_{\mathrm{d}}^{\prime}, \mathrm{T}_{\mathrm{d}}{ }^{\prime}, \mathrm{T}_{\mathrm{d}}{ }^{\prime \prime}\right)$ を求めた結果 を図 8 に示す。 2 重ダンパに起因する次次過渡電流成分を 分離でき、対応するリアクタンス、時定数が得られた。

\section{（5）負荷遮断試験結果}

電機子電流がほぼ直軸成分のみの負荷条件から負荷遮断 を行い、端子電圧の減衰波形から、図 8 と同様の解析を行 い $\mathrm{d}$ 軸のリアクタンス $\left(\mathrm{X}_{\mathrm{d}}, \mathrm{X}_{\mathrm{d}}{ }^{\prime}, \mathrm{X}_{\mathrm{d}}{ }^{\prime}, \mathrm{X}_{\mathrm{d}}{ }^{\prime \prime}\right)$ 、および時定数 （ $\mathrm{T}_{d}^{\prime}, \mathrm{T}_{\mathrm{d}}{ }^{\prime}, \mathrm{T}_{\mathrm{d}}{ }^{\prime \prime}$ ) を求めた。リアクタンス実測值は $\mathrm{X}_{\mathrm{d}}=0.41$ $\mathrm{X}_{d}^{\prime}=0.32, \mathrm{X}_{d} "=0.25, \mathrm{X}_{\mathrm{d}}$ "”=0.19p. u. であった。

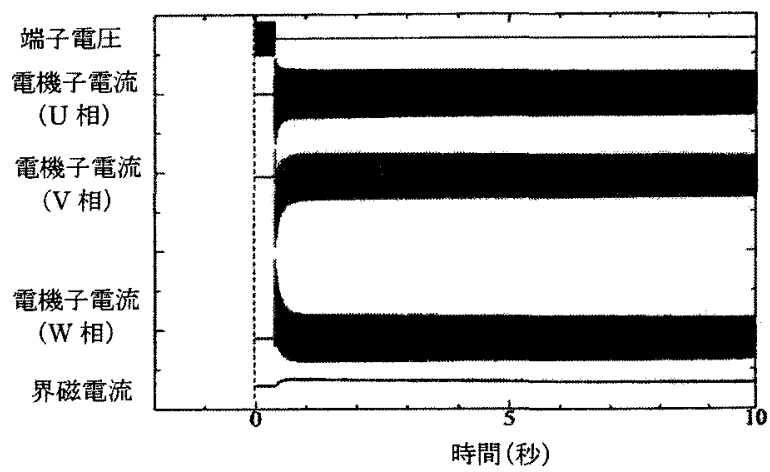

図 7 三相突発短絡時の電流波形

Fig.7. Short circuit current wave form
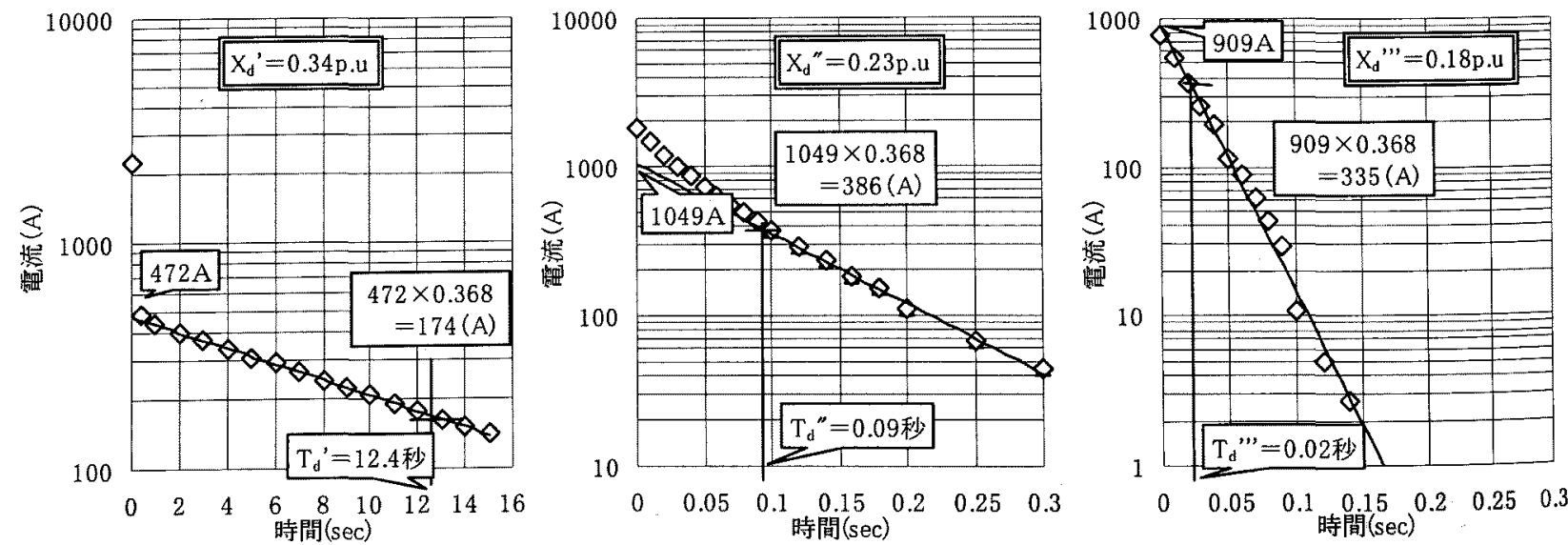

図 8 突発短絡電流波形からリアクタンスの算出

Fig.8. Analysis of short circuit current waveform 
(6) 試験結果のまとめ

(1)〜6)の試験により、定数計測を実施した結果を表 9 に まとめて示す。超電導発電機には突極性がないことが確認 されているため、表示は $\mathrm{d}$ 軸の定数のみとした。

\subsection{2 解析との対比}

現状の解析技術では、ダンパの導電率を考慮して発電機 全体をモデル化した三次元解析を行うことは困難であるこ とから、巻線の起磁カをカレントシートで表現した擬似三 次元解析 ${ }^{(7)}$ を適用した。本解析においては、電機子巻線の 直線部、端部の起磁力をカレントシートで表現し、その分 布を高調波まで展開することで起磁力分布を正確に考慮し た三次元解析を実施した。解析では、式 (1)の磁界の基礎微 分方程式を数值計算することで求めている。

$$
\begin{aligned}
& \frac{1}{r} \frac{\partial}{\partial r}\left(r \frac{\partial v}{\partial r}\right)+\frac{1}{r^{2}} \frac{\partial^{2} v}{\partial \theta^{2}}+\frac{\partial^{2} v}{\partial z^{2}}=0 \quad \cdots \cdots \cdots \cdot \text { 式 (1) } \\
& \left(\begin{array}{l}
v: \text { スカラポテンシャル } \quad v=u \cos (n \omega t-\theta) \quad \mathrm{AT} \\
u: 2 \text { 次元ポテンシャル }
\end{array}\right.
\end{aligned}
$$

回転子表面に第 2 種境界（ $\partial \mathrm{V} / \partial \mathrm{n}=0 ）$ を設定するこ とで、非同期磁界により回転子表面に誘導される渦電流の 影響を考虑した。 $\mathrm{X}_{\mathrm{d}}$ "”の解析では常温ダンパ表面に境界を 設定した。ポテンシャル分布解析結果を図 9 に示す。電機 子巻線に定格電流 $\left(I_{R}\right)$ を通電した場合の磁界分布から電 機子巻線鎖交磁束量 $\left(\phi_{\mathrm{R}}\right)$ を求め、式 $(2)$ により電機子巻線 の誘起電圧 ( $\left.\mathrm{V}_{\mathrm{si}}\right)$ を求めた。式 $(3)$ により定格電圧 $\left(\mathrm{V}_{\mathrm{R}}\right)$ との比から、リアクタンスを算出した。

$$
\begin{aligned}
& V_{S i}=k \cdot n \cdot \omega \cdot \Phi_{R}(\mathrm{~V}) \quad \cdots \cdots \cdots \cdot \text { 式 (2) } \\
& \left(\begin{array}{ll}
k: \text { 你数 } & n: \text { 実効ターン数 } \\
\omega: \text { 角速度 } & \Phi_{R}: \text { コイル鎖交磁束量 }
\end{array}\right. \\
& X=\frac{V_{S i}}{\sqrt{3} I_{R}} / \frac{V_{R}}{\sqrt{3} I_{R}}=\frac{V_{S i}}{V_{R}} \text { (p.u) …....式 (3) }
\end{aligned}
$$

$\mathrm{X}_{\mathrm{d}}$ "”解析值は 0.17p.u.と実測值とほほ一致しており、発電 機端部を考慮した過渡リアクタンスの解析が精度よく行え ることを確認した。表 9 には磁界が低温ダンパ、界磁巻線 で遮蔽されるとして求めたリアクタンス $\left(\mathrm{X}_{d} ， \mathrm{X}_{d}{ }^{\prime}\right)$ を併 せて示す。

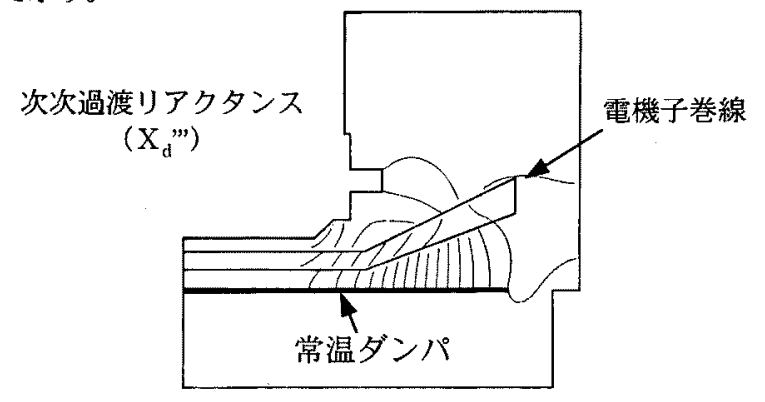

図970 MW超電導発電機の磁界解析結果

Fig.9. Potential distribution by quasi-3D analysis

\section{4. まとめ}

$70 \mathrm{MW}$ 級低速応型超電導発電機の無負荷飽和/短絡特性、 リアクタンスに関し、以下の結論が得られた。

(1) $70 \mathrm{MW}$ 級機の無負荷飽和特性/短絡特性を計測し同 期リアクタンスを求めた結果、0.42p.u と現用機の $1 / 4$ $\sim 1 / 5$ に低隇しており、超電導発電機の空心構造がリ アクタンスに与える効果を確認した。

(2) 発電機機内の磁束密度分布、無負荷飽和 /短絡特性、 同期リアクタンスともに電機子巻線の端部を考虑した 三次元解析で正確に求まることを示した。

(3) 二重ダンパに起因する次次過渡リアクタンスを三相乫 発短絡試験、負荷遮断試験から求めることができた。

(4)リアクタンスの過渡成分 $\left(\mathrm{X}_{d}, \mathrm{X}_{d}, \cdot \mathrm{X}_{\mathrm{d}}{ }^{\prime \prime}\right)$ は、巻線の 起磁力をカレントシートで表現した擬似三次元解析に

\begin{tabular}{|c|c|c|c|c|c|c|}
\hline & \multirow{2}{*}{ 項目 } & \multicolumn{3}{|c|}{ リアクタンス } & \multicolumn{2}{|c|}{ (p. u) } \\
\hline & & $X_{0}$ & $X_{d}^{\prime}$ & $X_{d}^{\prime \prime}$ & $X_{d}^{\prime \prime \prime}$ & $X_{2}$ \\
\hline \multirow{6}{*}{$\begin{array}{l}\text { 実 } \\
\text { 証 } \\
\text { 試 } \\
\text { 験 } \\
\text { 結 } \\
\text { 果 }\end{array}$} & $\begin{array}{c}\text { 無負荷飽和特性試験 } \\
\text { 三相短絡特性試験 }\end{array}$ & 0.42 & - & - & - & - \\
\hline & ダルトン・カメロン法 & - & - & - & 0.18 & 0.18 \\
\hline & ダンパ試験 & 0.42 & - & - & - & 0.17 \\
\hline & 単相短絡法 & - & - & - & - & 0.17 \\
\hline & 三相突発短絡試験 & - & 0.34 & 0.23 & 0.18 & - \\
\hline & 直軸負荷遮断試験 & 0.41 & 0.32 & 0.25 & 0.19 & - \\
\hline & 解析結果 & 0.43 & 0.32 & 0.26 & & \\
\hline
\end{tabular}
より、渦電流の影響を回転子表面の境界条件を設定し て考虑することで算出できることを示した。

表 $970 \mathrm{MW}$ 級機のリアクタンス（実測と解析の対比）

Table.9. Measured and analyzed reactance of 70MW model generator 
（5）（2）、（4）が精度良く解析できることを確認できたこと から、電機子巻線の端部発電効果を考虑した超電導発 電機の基本設計技術を確立できたと考える。 これらの解析技術は、次期開発である、200 MWパ イロット機の基本設計に適用していく方針である。

本研究は、通商産業省工業技術院のニューサンシャイン 計画「超電導電力応用技術開発」の一環として、新エネル ギー・産業技術総合開発機構（NEDO）からの委託によ り実施したものである。

(平成11年 3 月 5 日受付)

\section{参考文献}

（1）井上他「7 $0 \mathrm{MW}$ 級超電導発電機の開発・実証試験の 状況」, 平成 9 年度電気学会超電導応用電力機器 - 回転 機合同研究会, ASC-97-25, RM-97-38

（2）前田進、泉昭文、上田明紀、阪部茂一、米谷晴之、 野村達衛、田中正昭:「超電導発電機のかご形ダンパ構 造の実験研究」電学論B, 111 巻 4 号, 平成 3 年

（3）上田明紀、平尾俊樹、小林俊、吉村秀人、中村幸夫 :

「超電導発電機のロータ部分モデルの回転中のクエンチ 特性」電気学会研究資料 RM-92-144, SA-92-81

（4）平尾俊樹、鈴木一市、上田明紀、小寺溢男、下畑賢司、 吉村秀人、豊田勝義 : 「70MW級級低速応型超電導発電 機のロータの回転励磁試験」電気学会研究会資料 ASC97-27, RM-97-40

（5）平尾俊樹、草深浩、今井義博、渋谷正豊、上田明紀、 鈴木一市、前田進、塩原亮一：「7 $0 \mathrm{MW}$ 級高電流密度 型超電導発電機の基本特性」電気学会研究会資料 ASC-98-21、RM-98-35

（6）米谷晴之 :「タービン発電機の巻線端部に働く電磁力の 三次元解析」電気学会研究会資料 SA-96-24, RM-96-74

（7）野村達衛 :「発電機端部の固定子巻線に㗢く電磁力」 三菱電機技報 vol. 46 , No. 10,1972

前田 進 （正員） 1952 年 10 月 1 日生。1977 年

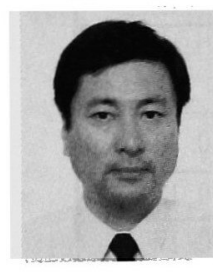
北海道大学大学院工学研究科電気工学専 攻修士課程修了。同年 4 月三菱電機 (株) 入社。電力・産業システム事業所に勤務。 主としてタービン発電機、超電導発電機 の設計・開発に従事。1998 年日本電機工 業会電機工業技術功績者会長賞受賞。
増永 顕

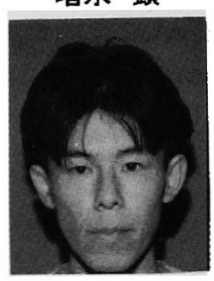

1971 年 8 月 17 日生。1996 年横浜国立大学 大学院工学研究科生産工学専攻修士課程 修了。同年 4 月三菱電機 (株) 入社。電力・ 産業システム事業所に勤務。タービン発 電機、超電導発電機の設計·開発に従事。

鈴木 一市（正員） 1952 年 1 月 14 日生。1976 年

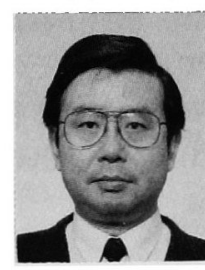
名古屋大学大学院工学研究科電気工学専 攻修士課程修了。同年 4 月三菱電機 (株) 入社。電力・産業システム事業所に勤務。 主としてタービン発電機、超電導発電機 の設計·開発に従事。1998 年日本電機工業 会電機工業技術功績者会長賞受賞。

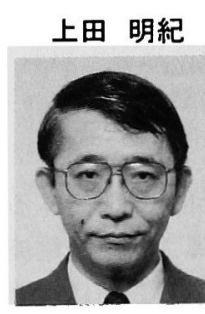

（正員） 1948 年 2 月 6 日生。1972 年 東京大学大学院工学研究科機械工学専攻 修士課程修了。同年 4 月三菱電機 (株) 入社。電力・産業システム事業所に勤務。 主としてタービン発電機、超電導発電機 の設計·開発に従事。1998 年電気学会進歩 賞受賞。日本機械学会会員。

米谷 晴之 （正員） 1964 年 3 月 3 日生。1989 年

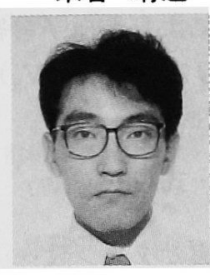
京都大学大学院工学研究科電気工学専攻 修士課程修了。同年 4 月三菱電機 (株) 入社。先端技術総合研究所に勤務。主と して電磁機器、超電導応用機器の電磁解 析の研究に従事。1998 年電気学会論文発 表賞受賞。I E E E 会員。

下畑 賢司 （正員） 1962 年 5 月 18 日生。1987 年 大阪大学大学院理学研究科物理専攻修士 課程修了。同年 4 月三菱電機 (株) 入社。 先端技術総合研究所に勤務。主として超 電導マグネットの開発に従事。低温工学 会会員。

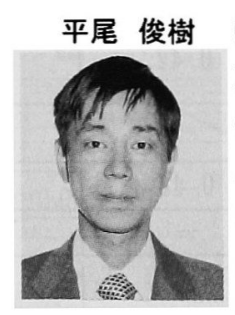

（正員） 1955 年 1 月 4 日生。1979 年 京都大学大学院工学研究科電気工学専攻 修士課程修了。同年 4 月三菱電機 (株) 入社。電力・産業システム事業所に勤務。 主としてタービン発電機、超電導発電機 の開発に従事。1997 年超電導関連機器材 料技術研究組合に出向、現在に至る。 